\title{
IMPRENSA BRASILEIRA: a intertextualidade entre o jornalismo e a literatura
}

\author{
The Brazilian Press: the Intertextuality between \\ Journalism and Literature
}

Nicoli Glória De Tassis ${ }^{1}$

\section{Resumo}

Este artigo investiga as contribuições do diálogo entre os campos jornalísticos e literários na conformação da imprensa brasileira. Para tanto, faremos uma revisão crítica da história do jornalismo impresso no Brasil e seus contornos estéticos, a partir de pesquisas prévias sobre o tema.

Palavras-chave: Jornalismo; Literatura; Imprensa; Narrativa.

\section{Abstract}

This article investigates the contributions of the dialogue between the journalistic and literary fields in the formation of the Brazilian press. For that, we will make a critical revision of the journalism history (printed media) in Brazil and its aesthetic contours, from previous research about the subject.

Keywords: Journalism; Literature; Press; Narrative.

\footnotetext{
Graduada em Comunicação Social (habilitações: Jornalismo e Publicidade e Propaganda) pela Universidade Vale do Rio Doce (Univale). Atualmente, é mestranda do curso de Pós-graduação em Comunicação da Universidade Federal de Minas Gerais (UFMG); bolsista da Capes e membro do Grupo de Pesquisa em Imagem e Sociabilidade da UFMG (GRIS). E-mail: nicolitassis@pop.com.br
} 


\section{Introdução}

A trajetória da imprensa no Brasil parece conformada pela estética literária (FERREIRA, 2003). A partir do século XIX, a presença de escritores nas redações brasileiras, e a constante publicação de fragmentos de romances nos periódicos são alguns dos indicativos dessa tendência. Durante o século XX, temos a explosão das crônicas e folhetins nas páginas dos jornais, confirmando mais uma vez que o fazer jornalístico encontra diversas raízes na literatura.

Em vários momentos da nossa história, a sua função social demandou uma construção narrativa mais ampla do que apenas noticiar fatos e acontecimentos. Mais do que informar, o jornalismo se presta, muitas vezes, a tecer uma leitura dos fatos, por meio da conclamação das questões históricas, culturais, políticas, econômicas e sociais que os atravessam. Assim como também objetivavam os romances naturalistas brasileiros, desde o final do século XIX.

Neste artigo, faremos uma breve revisão da história do jornalismo impresso no Brasil. Esse exercício será feito mediante uma revisão crítica da literatura disponível sobre o tema. Interessanos mapear os principais pontos de confluência entre as práticas jornalísticas e literárias, mapeando as suas contribuições para a conformação da imprensa brasileira.

\section{Os primeiros indícios da imprensa brasileira}

Décadas antes de assumir as peculiaridades que o tornam hoje um discurso, muitas vezes apresentado como distinto e independente do literário, o fazer jornalístico desenvolveu-se intimamente ligado com a literatura. Os jornais impressos na cultura ocidental - que em seus primórdios atuaram como uma importante arena de lutas políticas e divulgação de ideais partidários - traziam textos cuja estética se aproximava muito da literatura, sendo até então uma das únicas práticas que se dedicava à prosa. Dessa forma, o fazer literário se constituía num alicerce em que o jornalismo, como prática emergente, poderia buscar seus contornos em um primeiro momento.
Se ainda não estava conformado um estilo jornalístico próprio de se escrever, também não havia a figura do jornalista como se conhece atualmente: um profissional tecnicamente preparado para exercer um papel central na narrativa cotidiana dos acontecimentos e fatos sociais. Assim, os primeiros profissionais a escreverem para os jornais eram especialmente os literatos da época, homens afeitos às letras, preocupados especialmente com questões de ordem política, que contribuíram ainda mais para a conformação de uma estética literária nas páginas dos periódicos.

Contudo, ainda que tenhamos diversos exemplos de profissionais que se dedicaram aos jornais e aos livros simultaneamente, Costa (2005) afirma que a origem do jornalista se afasta da do escritor, na medida em que refletimos sobre a função e o imaginário social em torno dessas duas atividades. Apesar de suas inumeráveis interseções, o ofício jornalístico se diferenciaria do literário por um objetivo básico: a narração dos acontecimentos. Antes da sua profissionalização integral, que só ocorreu efetivamente no Brasil a partir do século XIX, a atividade jornalística foi exercida por diversas camadas sociais, indistintamente, sob a única exigência de que o "jornalista" em questão tivesse uma história, pressuposta real, para contar aos outros.

Nesse ponto, Kovach e Rosenstiel (2003, p. 9) evidenciam que curiosamente "desde as mais isoladas sociedades tribais na África até as mais remotas ilhas do Pacífico" são exigidas as mesmas características das pessoas que se predispõem a buscar informações e depois divulgá-las. "Queriam gente que pudesse se mexer rápido, apurar os dados com exatidão e contá-los de forma envolvente". Em suma, se as expectativas gerais em torno do jornalista não têm se modificado consideravelmente ao longo dos séculos, as formas de transmitir informações variam com o passar do tempo, de acordo com o cenário e as necessidades conjeturais de cada sociedade.

É consenso que o livro e a própria literatura são muito mais antigos do que a invenção de Gutenberg (século XV), contudo, pouco se procura saber sobre uma possível história dos jornais anterior à tipografia. Se levarmos em consideração uma definição mais ampla dos veículos de comunicação jornalística, podemos considerar que "jornal é a informação [...] de algum 
acontecimento contemporâneo conservado pelos símbolos." (RIZZINI, 1945, p. 11). Nessa perspectiva, Costa (2005) aponta os Acta diurna populi romani, veículos oficiais de divulgação das decisões políticas do Império Romano datados em 69 antes de Cristo, como os antecessores mais antigos do jornal. Esses diários, que originalmente divulgavam as atas do Senado do Império Romano, pouco a pouco teriam se tornado "folhas linguarudas" em que a população tinha notícia dos mais variados assuntos, de casamentos e divórcios a rixas, incêndios, bancarrotas e espetáculos (COSTA, 2005, p. 210).

Os bardos viajantes que reportavam e teciam comentários sobre os acontecimentos cotidianos nas feiras, mercados e cortes da Idade Média também são apontados como uma espécie de jornalistas pioneiros. Contudo, como desenvolveram a sua atividade de forma anônima, sem deixar sequer um registro escrito ou assinatura na história, considera-se que os primeiros "repórteres" tenham sido os correspondentes de viagens a terras distantes, como o escrivão Pero Vaz de Caminha, que relatou detalhadamente as suas impressões na chegada ao então "descoberto" Brasil, e o jesuíta José de Anchieta, que muito se ocupou de narrar a vida na nova terra. A literatura epistolar, como ficou conhecida posteriormente, conferiu prestígio ao gazetier ${ }^{2}$, entre os séculos XVI e XVIII. O sucesso do correspondente era proporcional à sua capacidade de informar os principais acontecimentos por meio de cartas com a maior precisão e o mais rápido possível. "De carta escrita por cortesia à reportagem por obrigação, dos assuntos escolhidos de acordo com o interesse comum dos correspondentes a todo o tipo de informação, do destinatário amigo ao assinante disposto a pagar, atravessou-se um limiar." (KUNCZIK, 2001, p. 58).

Aos poucos, os correspondentes viajantes embarcados na rota das grandes navegações pelos governantes, Igreja e casas comerciais de renome começaram a perceber que a função de reportar os acontecimentos poderia alcançar mais pessoas, tornando-se um ofício bastante lucrativo. Era um prenúncio da instituição do jornalismo como prática mercantil. A princípio, tal proposta era impossível já que os destinatários guardavam as informações em segredo, como a carta do "descobrimento" do Brasil, considerada confidencial pelos detalhes preciosos e estratégicos que forneciam sobre a nova terra. Foi em Veneza, no século XVI, que pela primeira vez as notícias chegaram ao público, com a cópia e comercialização das cartas de viagem. "O personagem do jornalista já nasce assim sob o signo da mercantilização da escrita." " (COSTA, 2005, p. 211).

Os pequenos jornais franceses escritos à mão - as nouvellistes-à-la-main ${ }^{4}$ - já disputavam o furo jornalístico. Tinham duas vantagens primordiais sobre os veículos impressos: a maior rapidez de sua produção e a possibilidade de escapar mais facilmente da censura. Por isso, a despeito de haver disponíveis recursos técnicos mais avançados, essas publicações artesanais perduraram ainda por bastante tempo na Europa e também no Brasil. Após 13 anos da tardia implantação da tipografia em nosso país, em 1821, o Conciliador Maranbense ainda era fornecido em cópias manuscritas. Em São Paulo, o Farol Paulistano resistiu até 1823. Os principais motivos para tal resistência são de ordem políticaeconômica: as tipografias necessitavam de licença governamental para funcionar, permissão esta que só era concedida a quem fosse considerado interessante para o poder vigente; e era um investimento de capital bastante alto.

Os utensílios de um redator de gazeta limitamse a uma pena, um tinteiro e uma folha de papel; copiado o panfleto e posto em mãos seguras, nada lhe trairá o segredo. Uma tipografia, ao contrário, exigiria equipamento importante e serviria para desvendar os mistérios que se procuram ocultar. (RIZZINI, 1945, p. 65).

Desde a publicação dos primeiros jornais, a Coroa portuguesa já percebia o potencial de influência social dos veículos de comunicação, ainda que o seu alcance fosse bem menos significativo do que temos hoje. A censura prévia e a concessão controlada de licenças de

\footnotetext{
2 Nome dado ao correspondente de viagem.

3 A remuneração, que balizou os primórdios da atividade jornalística, também se encontra na instituição oficial da profissão no Brasil. O decreto-lei de número 972, artigo 2 (17/10/1969) diz que: "A profissão de jornalista compreende, privativamente, o exercício habitual e remunerado" da execução de funções que vão desde a redação até a diagramação dos periódicos.

Geralmente eram oferecidos no formato in-quarto, escrito nos dois lados da folha, sem cabeçalho.
} 
funcionamento demonstram que os periódicos serviam como importante arena política no período, que poderiam se tornar importantes aliados dos interesses da metrópole ou inimigos ferozes do sistema colonial, caso não fossem bem controlados. É interessante observar que tal prática atravessou os séculos no Brasil, sendo que temos o exemplo recente mais expressivo no período da Ditadura Militar, quando os periódicos impressos sofreram intensa censura e novas freqüências de rádio e canais de televisão só eram concedidos a aliados políticos do regime repressivo.

Ainda que a manutenção de jornais escritos à mão se constituísse na opção mais viável para se burlar o cerceamento político e econômico no Brasil Colônia, chegaria o inevitável momento de se render aos encantos da tecnologia. Contudo, não era apenas a concorrência com os veículos impressos que decretaria o fim dos manuscritos. A Inquisição perseguiu diversos pasquins que durante o período colonial tentaram driblar a censura dos textos impressos. Oficinas foram queimadas a mando da Coroa portuguesa por publicarem trabalhos considerados politicamente nocivos, demonstrando a intransigência da metrópole ao livre-pensamento escrito na colônia.

O constante terror intelectual imposto a mão-de-ferro por Portugal a suas colônias levou o nosso primeiro jornalista a publicar além mar o combativo Correio Braziliense. Depois de escapar dos cárceres da Inquisição, Hipólito da Costa edita - entre 1808 e 1821, em Londres - o jornal que ousou desafiar explicitamente a ordem portuguesa que proibia o exercício da atividade jornalística na colônia. Ex-diretor da Imprensa Régia de Portugal, Hipólito encontrava-se exilado em Londres desde que fugira da prisão e de lá enviava seus editoriais. Apesar de ter sido escrito e impresso na Inglaterra, a maioria dos pesquisadores admite o Correio Braziliense - também chamado de Armazém Literário - como o marco inicial da imprensa no Brasil, intimamente ligada a lutas ideológicas políticas e à estética literária do período.

O seu formato é um indicativo da proximidade entre os jornais e livros, há apenas dois séculos. Se atualmente são demarcados por modos de escrever, editar e publicar bastante distintos, em 1808 era perfeitamente possível confundi-los. O Correio era impresso no mesmo formato usado para livros (in-oitavo), e a numeração de suas páginas dava seqüência nas edições seguintes. Além disso, exemplares avulsos do jornal eram vendidos em volumes encadernados, em capa dura. A diferenciação entre os formatos só começa a acontecer em meados do século XIX, quando os jornais passam a ter uma distribuição mais ampliada.

Em 1821, o Correio faliu por falta de assinantes, o mesmo motivo do fracasso de $O$ Patriota. Lançado em janeiro de 1813, esse jornal circulou menos de dois anos no país, contudo reuniu alguns dos principais escritores jornalistas do período, como o aristocrata Borges de Barros e o militante Silva Alvarenga. O primeiro é considerado um dos precursores do romantismo no Brasil: assinava seus artigos apenas como "B"; seu livro Poesias oferecidas às senhoras brasileiras por um baiano foi publicado sem o nome do autor, em Paris; e sua única obra devidamente assinada foi Os túmulos. Borges de Barros é um legítimo representante do velho regime literário no Brasil, marcado por homens das letras que pouca distinção faziam entre a prática do jornalismo e da literatura. Já Silva Alvarenga ${ }^{5}$ é o embrião do escritor que faria da atividade jornalística um degrau para divulgar o seu nome e proporcionar a publicação de trabalhos considerados de maior fôlego. Foi um grande militante da causa literária, sendo um dos fundadores da Sociedade Literária e do jornal $O$ Patriota. Também se revelou um militante político, participando ativamente da insurreição de Ouro Preto, pela qual passou três anos preso.

Dois homens tão distintos - de um lado o senhor de Engenhos Borges de Barros, do outro o mulato pobre Silva Alvarenga - encontram nos embates culturais e políticos um mesmo caminho, trabalhando lado a lado na redação do jornal. Ambos profissionais da informação e amantes das letras: exemplares de um tempo em que jornalismo e literatura sofriam os mesmos percalços, constantemente imbricados com questões de ordem política. E a eles se somam vários outros exemplos. Assim como a poesia de Gregório de Matos foi censurada no Brasil no século XVII, a tipografia e a imprensa também foram proibidas até o século XIX. Mesmo assim, os manuscritos que

\footnotetext{
5 "Nascido de uma família humilde de Vila Rica, de pai músico e mãe negra, estudou em Coimbra, publicou poemas em louvor de seu mecenas, o marquês de Pombal, trabalhou como advogado e professor de retórica e poética, e morreu com um nome respeitado no Rio de Janeiro."
} 
Imprensa brasileira: a intertextualidade entre o jornalismo e a literatura

antecederam tanto os primeiros livros, quanto os primeiros jornais, encararam o desafio de driblar as ordens restritivas e cumpriram o importante papel de difundir o crescente sentimento nativista da colônia. Poetas barrocos e árcades usaram recursos literários para denunciar desmandos políticos, trazendo na forma de literatura os fatos e a crítica social que depois alimentariam, em grande medida, o fazer jornalístico.

Apesar das aproximações tão evidentes entre a prática do jornalismo e da literatura no período que antecedeu a chegada da imprensa do Brasil, não podemos afirmar que os poetas foram jornalistas, no sentido estrito do termo. Apenas buscamos chamar a atenção para os limites tênues entre a função e a relação social desempenhadas pelos dois fazeres desde os seus primórdios no Brasil. Assim como a poesia, cartas e sermões desempenharam um papel fundamental na crítica nacional e informação, num período em que a produção de jornais e livros era proibida em nosso país. Dessa forma, as funções básicas do jornalismo contemporâneo (informar, orientar e interpretar a realidade social) já eram desempenhadas por esses veículos "parajornalísticos", uma vez que o primeiro jornal efetivamente produzido no país - A Gazeta do Rio de Janeiro (uma adaptação da Gazeta de Lisboa) - só surgiria em 1808, e mesmo assim seria uma publicação a serviço dos interesses do Estado Português.

Outro ponto que comprova essa proximidade é que os livros e jornais brasileiros nasceram praticamente juntos e foram publicados pela mesma editora. O primeiro livro, Observações sobre o comércio franco do Brasil, é filho da mesma tipografia que a Gazeta do Rio de Janeiro. Nesse período, a relação entre os campos jornalístico e literário se dava de forma bastante imbricada: contavam basicamente com os mesmos jornalistas escritores; tinham os mesmos objetivos de busca de uma identidade para o Brasil e mobilização política; sofriam juntamente o controle da metrópole sob o seu conteúdo; e se constituíam em instrumentos de denúncia social e ideais políticos. Nesse ponto, o jornalismo parece despontar mais aos olhos do público, pela sua vertente mais informativa e direta, conferindo status à figura do jornalista. "O processo de Independência acentuou esse caráter missionário: o intelectual considerado como mentor da sociedade, voltado para a aplicação prática das idéias. A imprensa foi o meio privilegiado de sua ação." (LUSTOSA, 2000, p. 33).

Num período conduzido pela mão inquisitória da metrópole, a possibilidade de ser livre movimentou uma geração de "jornalistas estadistas". Pessoas de diversos níveis sociais, unidas pela facilidade da escrita e pelo ideal de mudar os rumos do país com as suas palavras. Nesse contexto, não é difícil pressupor por que os versos e romances imaginativos cedem lugar para textos que promovam reflexões e debates sobre a realidade social. Nas redações clandestinas, reúnem-se as penas de escritores renomados ou mesmo de cidadãos simples, que buscavam nos periódicos a chance de inserir a sua voz no cotidiano e assim modificar a história, já que pelas vias da política era quase impossível, num período de acesso ao poder tão restrito e de direitos cerceados.

Nesse contexto, não é de se estranhar que um dos principais escritores jornalistas do período fosse também um dos políticos mais destacados do Império: José Bonifácio de Andrade e Silva ${ }^{6}$, conhecido como o "Patriarca da Independência". Ele assumiu o cargo de diretor da Imprensa Régia e mais tarde se tornou inspetor dos Estabelecimentos Literários, sendo responsável pela censura de todas as obras publicadas no Brasil. Oficialmente, só editava jornais e panfletos de conteúdo conservador. Contudo, recorreu a tipografias particulares para publicar, de forma clandestina, diversos outros materiais com forte vertente crítica. Num período em que os jornais eram mais panfletos políticos do que veículos informativos e os pasquins nasciam e morriam conforme os interesses de seus redatores, temos a figura do jornalista que mais se assemelha a um militante em campanha. Nos periódicos, os textos não se aproximam nem da estética dos romances, nem do formato da notícia contemporânea: são melhores definidos como manifestos ideológicos.

\section{0 folhetim, a crônica e a mercantilização dos jornais}

Em 1838 - dois anos depois da inserção de um capítulo de romance no jornal francês $L a$

\footnotetext{
6 Ele foi o responsável pela publicação de nove pequenos jornais e 32 panfletos políticos de perfil conservador, além de um livro, sob pseudônimo, Poesias de Amério Elísio (1825).
} 
Presse - a febre do folhetim chega à imprensa brasileira, inaugurando uma era literária em nossos jornais. Logo que O Capitão Paulo, de Alexandre Dumas, é traduzido e publicado pelo Jornal do Commércio, os escritores nacionais se movimentam em torno da novidade. Passaram pelo jornalismo e pelo folhetim, por exemplo, dois autores que posteriormente iriam brigar pela honra de terem escrito o primeiro romance da literatura brasileira: Antônio Gonçalves Teixeira e Souza ${ }^{7}$ ( $O$ filho do Pescador, 1843) e Joaquim Manuel de Macedo ${ }^{8}$ ( $A$ moreninha, 1844). A eles se somam diversos outros literatos, especialmente os de origem humilde, que buscam na imprensa um espaço de profissionalização e inserção social. Vários escritores, jornalistas renomados, entraram na imprensa e na literatura brasileira pelo "andar de baixo", desempenhando durante vários anos funções consideradas de menor prestígio, tais como o próprio Teixeira de Souza, Manuel Antônio de Almeida, Paula Brito e Machado de Assis, apenas para citar alguns exemplos.

Essa geração de jornalistas escritores é testemunha de um momento crucial na história da literatura e da imprensa brasileira. A mudança começa em 1840, quanto do golpe da maioridade de D. Pedro II inaugura um novo tempo no jornalismo do Brasil. Os jornais panfletários e os pasquins políticos, que tiveram o seu momento de maior projeção a partir da volta de D. João VI a Portugal, cedem lugar para uma imprensa menos militante. Assim, os homens das letras encontram maior espaço nos jornais, substituindo em grande parte o ofício dos jornalistas revolucionários. A inserção do folhetim nos periódicos começa a formar um público para a ficção nacional e também para os jornais. A imprensa demonstrava um incrível potencial de alcance em um país de poucos leitores e livrarias. Às portas do século XX, praticamente todos os principais escritores do período publicariam seus romances primeiro nos jornais, para posteriormente lançar seus livros.
O jornalismo se torna, assim, a opção mais viável para os aspirantes a escritor. José de Alencar? é um dos principais exemplos dessa geração. Impulsionado pela febre do folhetim, ele se tornou conhecido após o grande sucesso inesperado de Cinco minutos, um trabalho que, a princípio, só tinha finalidade mercantil, já que foi escrito para servir como brinde aos assinantes do Diário do Rio de Janeiro, no fim de 1856. No ano seguinte, Alencar despontou na vida literária, com o lançamento de dois romances, publicados também em forma de folhetim, entre eles o inesquecível $O$ Guarani, e três peças teatrais. Além disso, investiu posteriormente na carreira política. Mesmo assim, nunca abandonou o ofício na imprensa.

A popularidade de Alencar nos jornais acaba por gerar o desprezo da crítica, impasse sofrido também por muitos escritores jornalistas ao longo do século XX, condenados a um eterno legado de inferioridade sob a acusação de terem se "prostituído" ao misturar arte literária e ofício jornalístico. O lançamento de O Guarani é marcado por um total silêncio da roda letrada. Contudo, quando foi publicada em folhetim, a mesma obra se tornou um verdadeiro sucesso de público, o que aponta para uma preferência dos leitores pelos periódicos em detrimento dos livros no Brasil do Segundo Reinado. Assim também ocorreu com a publicação de Memórias de um sargento de milícias, de Manuel Antônio de Almeida: bemsucedida em folhetim (1852-1853) e pouco aceita em forma de livro, em 1954. Machado de Assis é outro exemplo de como as páginas dos jornais poderiam conquistar leitores fiéis: A mão e a luva, Helena e Iaiá Garcia foram serializados e acompanhados com ansiedade a cada novo exemplar.

O casamento entre o jornalismo e a literatura gerou obras e autores híbridos. Temos em O subterrâneo do Morro do Castelo, de Lima Barreto, um dos melhores e mais antigos exemplos

\footnotetext{
7 Também conhecido como "Camões africano", Teixeira e Souza foi carpinteiro, tipógrafo, caixeiro da livraria de Paula Brito, revisor de provas, jornalista e folhetinista. Chegou abrir uma oficina tipográfica e uma loja de objetos de escritórios. Contudo, tempos depois, falido, teve que procurar a ajuda de pessoas importantes que havia conhecido em seus diversos ofícios anteriores. Terminou como escrivão, em 1861, curiosamente quatro décadas antes de Lima Barreto lançar Recordações do escrivão Isaías Caminha. Essa obra conta a história de um talentoso jovem negro que, assim como Teixeira e Souza, experimenta altos e baixos na prática jornalística e termina os seus dias como escrivão.

8 Homem importante na sociedade de seu tempo, Macedo foi médico, professor dos filhos da princesa Isabel e deputado por diversas vezes. Além disso, fundou a revista Guanabara e foi o redator de A nação e do Correio Mercantil, por onde posteriormente passaram renomados escritores, como José de Alencar.

9 É considerado o principal escritor do Romantismo brasileiro.
} 
de tal hibridização no país. A obra, lançada primeiramente em folhetim, em 1905, no Correio da Manhã, sem assinatura, é uma mistura de uma história de amor $^{10}$ com uma suposta reportagem sobre as escavações para a criação da avenida Central, conhecida atualmente como Rio Branco, símbolo do projeto de modernização da cidade do Rio de Janeiro, liderado por Pereira Passos.

Nesse folhetim, encontramos a ficção entremeada de relatos jornalísticos, registrando como as insistentes escavações em busca de objetos de ouro e prata, moedas antigas e uma grande biblioteca soterrada não conseguiram êxito. Até que com o correr dos trabalhos, um dos operários deparou-se com uma galeria escondida (1,60 metros de altura por meio metro de largura). A descoberta, claro, chama a atenção do repórter. Fazendo uso da primeira pessoa em sua narrativa, Lima Barreto deixa nesse folhetimreportagem um registro detalhado das transformações de uma cidade colonial rumo à modernidade. Personagens fictícios se misturam com reais, inaugurando um procedimento que se consolidaria ao longo do século XX, passando inclusive pelos criticados romances-reportagem de 1960, e encontraria sua maior expressão na literatura pós-moderna.

Por ser um gênero considerado menos nobre na literatura e não poder ser enquadrado sob uma classificação precisa, o folhetim "certamente encorajou os jovens jornalistas folhetinistas patrícios a não se acanharem diante da palavra escrita", desenvolvendo novas maneiras de narrar a realidade social e atrair o público leitor (MEYER apud CÂNDIDO, 1992, p. 127). Ele ainda seria a materialização da mistura entre arte e mercado, por sua relação com a nascente indústria cultural, inaugurando novos rumos para o fazer jornalístico e literário. Mesmo que grandes escritores da literatura internacional, tais como Dostoievski, Dickens, Balzac e Flaubert, assim como os brasileiros Machado de Assis e José de Alencar, tenham publicado obras posteriormente consideradas de grande valor literário, o gênero ficou marcado como uma subliteratura, subjugada por interesses comerciais. Mesmo que o indivíduo criador, o autor, deseje consagrar-se, a produção é agora progressivamente coletiva e guiada primordialmente pelas leis do mercado (SODRÉ, 1997).

Para manter a fórmula que prendia o público e, conseqüentemente, garantir a crescente vendagem dos jornais, os escritores precisavam de técnicas que iam muito além do simples retalhamento dos romances. Era necessário criar ganchos, manter o suspense, resgatar sempre o contexto da história e dos personagens, a fim de garantir a unidade da narrativa sem deixar de surpreender, mantendo assim os antigos leitores e possibilitando o acesso a qualquer momento de novos. Sem contar certa dose de versatilidade, já que a narrativa poderia se prolongar ou encurtar de repente, dependendo da aceitação do público. O folhetim teria uma vida bastante produtiva nas páginas dos nossos periódicos. Somente em meados do século XX, com a expulsão literária dos jornais, tornaria-se um gênero ameaçado de extinção. Encontramos em Nelson Rodrigues o último grande folhetinista brasileiro. Era o tipo de escritor jornalista que não temia cruzar as fronteiras da ficção em suas reportagens. Eu não via nenhuma dessemelhança entre literatura e jornalismo. Já ao escrever o primeiro atropelamento, me comovi como se fosse a minha estréia literária (RODRIGUES, 1995).

Repórter estreante, com apenas 13 anos, Nelson já em sua primeira nota se deparou com a tentação de acrescentar elementos ficcionais - uma vela e uma senhora de preto - para dar maior dramaticidade àquelas poucas linhas. Nos trabalhos posteriores, a sua veia de ficcionista se mostrava cada vez mais evidente. Tornou-se conhecido nas redações pela capacidade de inventar histórias fantásticas a partir de um mísero telefonema à delegacia. A partir de informações difusas, criava diálogos, cenários e tramas inteiras. O sensacionalismo de suas narrativas seria a sua principal ambição até o fim da vida. Narrar crimes passionais se tornaria uma verdadeira obsessão em sua carreira. Assim, Nelson considerava necessário abandonar o rigor jornalístico da face objetiva das coisas rumo a uma narrativa mais quente e vigorosa,

\footnotetext{
10 A trama de D. Garça se passa em 1709 e tem como pano de fundo a invasão do Rio de Janeiro por piratas franceses. A história é recheada de detalhes que enriqueceram o folhetim de Lima Barreto, tais como: padres que não se comportavam de acordo com "santo ofício", paixões impossíveis, o rapto de uma bela condessa italiana e a lenda de um tesouro valiosíssimo que os jesuítas teriam supostamente escondido nas fundações do convento, para impedir um provável confisco durante a expulsão deles do Brasil, exigida pelo Marquês de Pombal.
} 
mesmo que isso representasse inserir elementos inventados na narrativa de fatos reais.

Nessa perspectiva, não é de se estranhar que os personagens do folhetim e da reportagem sensacionalista sejam construídos de forma tão semelhante. Ambos são protagonistas de temas perturbadores, desenvolvidos com altas doses de dramaticidade, com a assumida intenção de chocar um leitor envolvido numa teia de suspense. Mesmo com o fim dos folhetins nas páginas dos jornais, percebemos nos romances-reportagem do período da Ditadura Militar essa mesma tendência ao sensacionalismo na composição das tramas e personagens, reflexo de uma tradição que remete ao início do século XX, quando o jornalismo sensacionalista ${ }^{11}$, misto de notícia e entretenimento, modificou profundamente o modo de fazer imprensa, traçando os rumos do que se convencionou chamar "a era do repórter". No Brasil, assim como em países como os Estados Unidos e a França, os repórteres tornaram-se conhecidos por suas matérias, mas também por se tornarem, em muitos casos, atores dos dramas que reportavam (FRUS, 1994).

Já nas primeiras décadas do século XX, o repórter policial se tornou um dos profissionais mais importantes da redação, ficando atrás em prestígio somente do redator de política. Esse era um dos motivos que atraíam Nelson Rodrigues e outros escritores jornalistas para a editoria de polícia, além da possibilidade de viver uma "experiência shakesperiana", num misto de ficção, dramaturgia e jornalismo. (RODRIGUES, 1995, p. 136).

Por todas as interlocuções evidenciadas até aqui entre os folhetins e o jornalismo sensacionalista, não demoraria muito para que os donos de jornais percebessem que os seus repórteres policiais dariam ótimos folhetinistas. $\mathrm{Na}$ primeira metade do século XX, os folhetins se tornaram uma espécie de "curinga" para os periódicos que precisassem aumentar a tiragem. A princípio, apelava-se para a tradução de uma história publicada anteriormente nos Estados Unidos ou na França. Essa era a situação de $O$
Jornal, por exemplo, que em tempos passados já havia sido o principal veículo dos Diários Associados, mas que não passava dos 3 mil exemplares por dia, em 1944. Nelson Rodrigues é um dos escritores jornalistas que vai aproveitar esse filão do mercado. Ao saber que O Jornal tinha o interesse de comprar um folhetim, teve a idéia de produzir Meu destino é pecar, sob a condição de usar um pseudônimo - Suzana Flag - em vez do próprio nome.

$\mathrm{Na}$ redação, Nelson produzia quatorze laudas todos os dias, ocupando uma página inteira do diário. Logo, a tiragem de O Jornal aumentou para 300 mil exemplares. A publicação posterior de Meu destino é pecar, em livro, vendeu 50 mil exemplares em apenas três meses, sendo que, dois anos depois, chegaria à marca de 300 mil obras vendidas. Em seguida, começou outro folhetim: Escravas do Amor, republicado em todos os jornais dos Diários Associados e, mais tarde, lançado também em livro. O êxito dessa segunda obra foi tão grande que "Suzana Flag" entrou definitivamente para a história dos best-sellers, ganhando inclusive uma autobiografia - Minha Vida - um dramalhão que se mostrou um sucesso absoluto de vendas, em 1946. Já em 1948, lançou outra obra com esse pseudônimo, intitulada Núpcias de Fogo. Ao mudar-se para o Diário da Noite, Nelson resolveu trocar Flag por Myrmais, que produziu apenas um trabalho: A mulber que amou demais. Posteriomente, passou a escrever uma coluna de correio sentimental. Três anos depois, já no Última Hora, "Nelson assumiu uma coluna de crônicas A Vida Como Ela É..., teoricamente baseada em fatos reais. E inventou tudo, ou quase tudo." (COSTA, 2005, p. 246).

Segundo Süssekind (1990), foi o Espelho Diamantino que, em 1828, introduziu no Brasil a idéia de que todo jornal deveria ter um observador de costumes, que registrasse detalhadamente tudo o que presenciasse em suas andanças pela cidade. O trabalho desse flâneur dá origem a algo que se convencionaria chamar, tempos depois, de crônica de costumes. Os

\footnotetext{
${ }^{11}$ Foi introduzido nos Estados Unidos por Joseph Pulitzer, que em 1883 comprou o World, e por Willian Randolph Heast, quando se tornou o dono do New York Journal, em 1895. Ao se esvaziar da ênfase política que tinha guiado até o século XIX, a imprensa teve que conquistar o público de outra maneira. E descobriu que poderia atrair o mesmo segmento interessado nos folhetins, falando de crimes e escândalos que despertassem emoções fortes. (COSTA, 2005)
} 
Imprensa brasileira: a intertextualidade entre o jornalismo e a literatura

primeiros passos rumo à conformação desse gênero podem ser percebidos nos textos de tom satírico-moralista dos tipos e hábitos cotidianos da sociedade brasileira, escritos por: padre Lopes Gama, em O Carapuceiro (a partir de 1832); Josino do Nascimento Silvam, em O Cronista (1837); e Marins Pena, no Correio da Moda (1839). Mas é na segunda metade do século XIX que a crônica se consolida, com a contribuição de jornalistas como José de Alencar, Joaquim Manuel de Macedo e Machado de Assis que, no jornal, "antecipa procedimentos que utilizará mais tarde como escritor, como o apelo a um narrador não confiável e o constante diálogo com o leitor." (GRANJA, 2000, p. 16).

No século XX, a crônica deixa a sua função de cobertura do efêmero, herdada do jornalismo, para se assumir como um gênero próprio, quase autônomo. Tal autonomia não se refere ao anulamento de suas raízes nos periódicos jornalísticos, nem tampouco ao abandono da narrativa do cotidiano, mas ao livreacesso que esse gênero híbrido tem ao conto, à reportagem, ao ensaio, ao humorismo e até ao poema em forma de prosa, sem estar preso ao ato de informar. Com a divisão mais sistemática do trabalho nas redações, a informação se tornou primazia do jornalista. Ao cronista restou, especialmente, o entretenimento do público leitor e assim "a linguagem se tornou mais leve, mais descompromissada e (fato decisivo) se afastou da lógica argumentativa ou da crítica política, para penetrar poesia adentro." (CÂNDIDO, 1992, p. 15). Talvez seja por isso que a crônica chamou a atenção de tantos poetas, como Carlos Drummond de Andrade, que muito contribuiu para o desenvolvimento do gênero no Correio da Manhã , onde assinou uma coluna (1954-1968) e já era colaborador esporádico desde 1942; e posteriormente no Jornal do Brasil.

Os anos de 1930 marcam a consolidação da crônica moderna no Brasil, com as contribuições de Manuel Bandeira, Tarsila do Amaral, Mário e Oswald de Andrade, entre outros. Contudo, o tom da produção dos cronistas brasileiros seria definido pela geração posterior aos modernistas. Seguindo os passos de Drummond, muitos escritores mineiros invadiram as redações dos jornais, tais como Rubem Braga, Otto Lara Resende, Murilo Rubião, Paulo Mendes Campos, entre tantos de igual expressão. "Poucos, como Fernando Sabino, conseguiram se firmar logo de cara como cronistas. Para a maioria, a reportagem era o caminho natural e a crônica o prêmio de consolação." (COSTA, 2005, p. 252).

Muitos eram os atrativos para os apaixonados pelas letras se tornarem cronistas: o status privilegiado na redação em detrimento do repórter diário; a visibilidade que conferia prestígio junto ao público; o exercício cotidiano da escrita; e a remuneração no final do mês. Mesmo Drummond, considerado o maior poeta de seu tempo, sabia da dificuldade de se viver somente da literatura. Os seus sucessores também logo perceberam que o mercado para a poesia era bastante escasso. Assim, nada melhor do que buscar nas crônicas a possibilidade de trabalhar sua veia de poeta indiretamente. Rubem Braga foi o primeiro a marcar o seu nome na história da nossa literatura com esse gênero considerado menor. Como cronista em tempo integral, participou de um time de talentosos escritores (Paulo Mendes Campos, Sérgio Porto e Antônio Maria) que, nos anos de 1950, inauguraram a era de ouro da crônica brasileira.

Em meados do século XX, o espaço literário dentro das páginas dos jornais já se encontra bastante demarcado, restringindo-se, na maioria das vezes, a crônicas e colunas assinadas. A industrialização e profissionalização do campo do jornalismo transformariam veículos parajornalísticos - movidos muito mais por aspirações políticas e literárias do que pela prática jornalística em si - em verdadeiras empresas da informação. O Correio da Manhã, criado em 1901, acompanhou de perto todas essas mudanças estruturais que possibilitaram um crescimento acelerado do parque gráfico e do mercado editorial. Nos cinqüenta anos seguintes, a imprensa nacional mudaria completamente: surgiram as revistas ilustradas, a diagramação se tornou mais funcional, ao passo que o modelo norte-americano de texto conciso se tornou a grande fórmula para se fazer jornalismo factual. Estava inaugurada a era do jornalismo objetivo. Antes da chegada da televisão, jornais matutinos e vespertinos formariam um novo público leitor: A Manhã e O Globo (1925); Diário Carioca (1928) e Diário de Notícias (1930). 


\section{Considerações finais}

Com o crescimento da industrialização, a partir da década de 1920, os escritores que atuavam nos jornais já não eram considerados estrelas, como na época em que Olavo Bilac e Coelho Neto, entre tantos outros, abrilhantavam as páginas com seus longos exercícios literários. A esse novo homem das letras não caberia produzir contos ou poemas; deveria agora se dedicar a reportagens, entrevistar, corrigir textos, editar o conteúdo e a forma do jornal, além de chefiar as redações. Não foi na condição de criadores de narrativas admiráveis que Graciliano Ramos, Carlos Drummond de Andrade, Oswald de Andrade e toda essa geração de escritores atuaram na imprensa e sim como "jornalistas braçais" ou "operários da informação". Curiosamente, foram eles mesmos, os literatos, que trouxeram para o fazer jornalístico a estética e os preceitos de uma literatura moderna, que economizava palavras e primava pela informação, muito antes que os lides, sublides e pirâmides invertidas fossem copiados do modelo norte-americano.

Nesse ponto, existem fortes evidências da aproximação identitária dos projetos literário e jornalístico produzidos por autores realistas e modernistas brasileiros. Mesmo que o movimento de ruptura literária com a importação de modelos estrangeiros tenha se dado entre os anos de 1920 e 1930, e o jornalismo só tenha sido realmente sistematizado tal como conhecemos hoje por volta dos anos de 1950, ambos buscavam expulsar os mesmos intrusos: o uso exacerbado de adjetivos, a literatice e o beletrismo. Assim, não há dificuldades em se perceber por que os escritores movidos por esse projeto modernista teriam implantado tais modificações também na imprensa, ao assumir cargos importantes nas empresas jornalísticas. O preceito dos escritores da época de cortarem ao máximo as "gorduras" do texto, registrando com a maior precisão e economia possível as informações mais importantes, adequaria-se perfeitamente às propostas estéticas de qualquer manual de redação contemporâneo.

Se a literatura parnasiana foi separada da moderna na polêmica Semana da Arte Moderna, em 1922, a imprensa experimentaria tal impacto na década de 1950, com a introdução do lide. O terreno já vinha sendo preparado pelos próprios escritores jornalistas brasileiros há três décadas. Contudo, a importação do modelo de objetividade norte-americano consolidaria a expulsão do nariz-de-cera, ou seja, das intermináveis divagações que antecediam o núcleo da informação nas matérias jornalísticas. Jornalistas como Samuel Wainer, Danton Jobim e Alberto Dines foram essenciais nesse processo. Depois de passarem uma temporada nos Estados Unidos, ajudaram a construir uma nova base para o jornalismo brasileiro, com a adoção da pirâmide invertida, a desvinculação do repórter do redator, e a separação de notícia e opinião. A profissionalização - que só seria regulamentada no Brasil em 1969, com a exigência do diploma gradativamente daria vida própria à carreira jornalística, que deixa de ser apenas um meio viável para o aspirante a escritor conquistar o seu espaço.

A influência da imprensa francesa, mais prolixa e opinativa, dá lugar à americana, movida pelos ideais de uma narrativa concisa e direta. Apesar da ampla aceitação da nova proposta, nem todos se renderam aos seus pressupostos. Nelson Rodrigues, adepto ao sensacionalismo e a ficcionalização do texto jornalístico, chamou os copidesques de "idiotas da objetividade" (RODRIGUES, 1995, p. 46). Daí por diante, uma das tarefas da ditadura da objetividade seria firmar as fronteiras entre o jornalismo e a literatura. Curiosamente, o conceito de objetividade dos fatos tal como conhecemos hoje já era trabalhado, ainda que não tivesse essa nomenclatura, pelos jornalistas brasileiros como uma herança da ideologia divulgada pela Escola Literária do Realismo Social.

Esse conceito de realismo no jornalismo se firmava na idéia de que os fatos falam por si só. Assim, o realismo surge vinculado à objetividade, cuja proposta central é a adoção de um método científico de apuração jornalística. Os futuros jornalistas seriam formados com a perspectiva de que qualquer notícia a ser divulgada deveria passar pela prova e verificação dos dados e fontes. Em pouco tempo, o novo modelo tomou conta das redações. Os jornais combativos já não tinham mais espaço nessa configuração. A informação ocupa as páginas antes dominadas pela opinião. Os textos explicitamente interpretativos só são encontrados em cadernos especiais e colunas assinadas. 
A partir do início do século XIX, as transformações sociais experimentadas pela sociedade ocidental, especialmente pelos países europeus e os Estados Unidos, começam a modificar o fazer jornalístico. O jornalismo brasileiro, claro, seria também confrontado, posteriormente, por tais modificações. Segundo Genro Filho (1987, p. 167), nesse período "ocorreram grandes transformações na imprensa, coincidindo com a expansão mundial do capitalismo e o aparecimento de inovações tecnológicas ligadas diretamente à reprodução e circulação das informações", tais como a invenção do telégrafo, da rotativa e do linotipo, estabelecendo-se, assim, "as bases materiais e sociais para um novo tipo de jornalismo".

A necessidade de abordar as questões mundiais que passaram a afetar toda a sociedade impunha ao jornalismo um ritmo frenético de trabalho e o alcance de um público muito mais abrangente e heterogêneo. É o início de uma era de racionalidade capitalista que transformaria a prática jornalística em uma verdadeira indústria da informação. Surge então o modelo de jornalismo objetivo, como uma espécie de "grito de independência" dos pressupostos centrais do fazer literário, pautado pelo ideal de uma escrita imparcial, simples e concisa, que rejeitava a carga subjetiva e as alegorias literárias.

Contudo, a proximidade dos textos jornalísticos com os literários não é de todo abandonada, ainda que passe a ocupar um espaço cuidadosamente delimitado e, por vezes, "vigiado", como é a separação, no jornalismo americano, entre as notícias chamadas de hard e soft. Segundo Gans (1979), citado por Bird e Dardenne (1999, p. 264-265), essa dicotomia se baseia na divisão de matérias "importantes em oposição a interessantes". Ou ainda, conforme acrescentam os autores, "a notícia hard é informativa, enquanto a notícia soft é divertida".

Nessa perspectiva, ao jornalismo diário, pautado pelos ideais de objetividade e imparcialidade, caberia a cobertura dos fatos de "real interesse social", em um texto preciso e coeso, redigido sob a chancela da urgência da produção noticiosa factual. Já os demais acontecimentos, considerados "frios" ou de "interesse humano", poderiam incorporar elementos literários (ou seja, "ficcionais" ou "subjetivos"), encontrando a sua melhor expressão no universo da reportagem, que se opõe à notícia pelo maior tempo de produção e pelo tratamento estilístico mais cuidadoso.

Demarcam-se, assim, dois espaços convencionais que, ainda que não sejam tão rígidos como a dicotomia propõe, pautam, em maior ou menor grau, um certo imaginário coletivo da prática da profissão: o jornalismo impresso tradicional, supostamente autônomo e singular, rígido com relação às inconvenientes "intromissões" do modo de narrar da literatura; e outro mais "maleável", que permite interlocuções mais explícitas com o fazer literário que lhe deu suporte nos primórdios. Delimitações e categorizações à parte, no fazer diário tais regras sempre serão marcadas por exceções. Além disso, tentar apagar inteiramente os traços de uma origem pode se constituir num perigoso exercício de apagamento de si mesmo. Um vestígio, por menor que se apresente, sempre se manifestará, ainda que sob a forma de resistência.

\section{Referências}

BRASIL. Decreto-lei no 972 , de 17 de outubro de 1969. Dispõe sobre o exercício da profissão de jornalista. Disponível em: <http: // www.planalto.gov.br/ccivil_03/Decreto-lei/ Del0972.htm>. Acesso em: 17 ago. 2007.

BIRD, Elisabeth; DARDENNE, Robert. In: TRAQUINA, Nelson (Org.). Jornalismo: questões, teorias e estórias. 2. ed. Lisboa: Vega, 1999. p. 252-262.

CÂNDIDO, Antônio. A crônica: o gênero, sua fixação e transformações no Brasil. Rio de Janeiro: Unicamp, 1992.

COsTA, Cristiane. Pena de aluguel: escritores jornalistas no Brasil - 1904 a 2004. São Paulo: Companhia das Letras, 2005.

FERREIRA, Carlos Rogé. Literatura e jornalismo, práticas políticas: discursos e contradiscursos, O novo jornalismo, o romance-reportagem e os livrosreportagem. São Paulo: Edusp, 2003.

FRUS, Phillis. The politics and poetics of jounalism narrative. New York: Cambrige University, 1994.

GENRO FILHO, Adelmo. O segredo da pirâmide: para uma teoria marxista do jornalismo. Porto Alegre: Tchê, 1987. 
GRANJA, Lucia. Machado de Assis: escritor em formação. Campinas: Mercado de Letras, 2000.

KOVACH, Bill; ROSENSTIEL, Tom. Os elementos do jornalismo. São Paulo: Geração, 2003.

KUNCZIK, Michael. Conceitos de jornalismo. São Paulo: Edusp, 2001.

LUSTOSA, Isabel. Insultos impressos. São Paulo: Companhia das Letras, 2000.

RIZZINI, Carlos. O livro, o jornal e a tipografia no

Brasil - 1500-1822. Rio de Janeiro: Kosmos, 1945.
ROGRIGUES, Nelson. A cabra vadia. São Paulo: Companhia das Letras, 1995.

SODRÉ, Muniz. Reinventando a cultura. Petrópolis: Vozes, 1997.

SÜSSEKIND, Flora. O Brasil não é longe daqui. São Paulo: Companhia das Letras, 1990. 